\title{
Heart failure as a multi-system clinical syndrome - an experience in cohort of acutely decompensated patients
}

\author{
Niewydolność serca jako wielonarządowy zespół kliniczny - charakterystyka kliniczna chorych \\ hospitalizowanych z powodu zaostrzenia niewydolności serca
}

Abstract Background: Heart failure is a condition with diverse aetiology and pathogenesis. This is associated with higher rates of comorbidities, such as i.e. hypertension, atrial fibrillation chronic kidney disease, anaemia and iron deficiency. The purpose of this study was to characterise patients hospitalised due to acutely decompensated heart failure, with a particular emphasis on any comorbidities and laboratory test abnormalities. Material and methods: A total of 102 patients aged over 18 years, hospitalised due to acute decompensated heart failure. Thorough medical history (including any concomitant diseases) was obtained from all patients. They also underwent a clinical examination and biochemical tests. Results: The subjects included were mostly men (76.5\%) with ischemic aetiology (63.7\%). The most common comorbidity was hypertension (66.6\%), while hypotension affected only $2 \%$ of patients. The most common heart failure subtype was heart failure with reduced ejection fraction (60.8\%). The detected blood test abnormalities included elevated cystatin C levels in $94.7 \%$, hyperuricaemia in $75.5 \%$, anaemia in $55.9 \%$, and iron deficiency in $78.3 \%$ of patients. Conclusion: Most of acute decompensated heart failure patients suffer from comorbidities with a documented impact on prognosis. Cardiovascular decompensation poses a risk of multi-organ dysfunction and estimating its actual consequences requires a detailed assessment of complex laboratory tests, including levels of creatinine, cystatin C, uric acid, red blood cell parameters and iron metabolism parameters.

Keywords: acute heart failure, laboratory tests, kidney failure, creatinine, anaemia

Streszczenie Wstęp: Niewydolność serca jest jednostką chorobową o zróżnicowanej etiologii i patogenezie. Dodatkowo w grupie chorych z niewydolnością serca obserwuje się liczne choroby współistniejące, takie jak: nadciśnienie tętnicze, migotanie przedsionków, przewlekła choroba nerek, niedokrwistość i niedobór żelaza. Celem pracy jest charakterystyka pacjentów hospitalizowanych z powodu zaostrzenia niewydolności serca, ze szczególnym uwzględnieniem chorób współistniejących oraz nieprawidłowości w badaniach laboratoryjnych. Metody: Do badania włączono 102 chorych powyżej 18. roku życia, hospitalizowanych z powodu zaostrzenia objawów niewydolności serca. W badanej grupie zebrano szczegółowy wywiad dotyczący chorób współistniejących, dokonano oceny klinicznej oraz oznaczono parametry biochemiczne. Wyniki: Wśród chorych hospitalizowanych z powodu zaostrzenia niewydolności serca dominowali mężczyźni (76,5\%) i przeważała niedokrwienna etiologia niewydolności serca (63,7\%). Najczęstszą chorobą współistniejącą było nadciśnienie tętnicze (66,6\%), a hipotensja występowała u $2 \%$ chorych. Największą grupę stanowili chorzy z niewydolnością serca z obniżoną frakcją wyrzutową (60,8\%). Spośród nieprawidłowości w badaniach laboratoryjnych podwyższone stężenie cystatyny C stwierdzono u 94,7\% chorych, a hiperurykemię u 75,5\%. Niedokrwistość występowała u 55,9\%, a niedobór żelaza u 78,3\% chorych. Wnioski: Chorzy z niewydolnością serca są szczególnie trudną grupą, w związku z występowaniem licznych chorób współistniejących, często mających wpływ na rokowanie. Dekompensacja układu sercowo-naczyniowego stwarza ryzyko dysfunkcji wielu narządów, co wymaga szczegółowej oceny biochemicznej, w tym oznaczeń stężeń kreatyniny, cystatyny C, kwasu moczowego, parametrów czerwonokrwinkowych i parametrów metabolizmu żelaza.

Słowa kluczowe: ostra niewydolność serca, badania laboratoryjne, niewydolność nerek, kreatynina, niedokrwistość 


\section{INTRODUCTION}

$\mathrm{H}$ eart failure (HF) is currently one of the few conditions whose prognosis has not improved despite rapid advances in medicine ${ }^{(1)}$. An estimated $2 \%$ of the general population suffers from $\mathrm{HF}^{(2)}$, with the proportion exceeding $10 \%$ in people over 70 years of age ${ }^{(3)}$. Due to its prolonged negative effects on the patients' quality of life and ability to work, HF carries a high social burden ${ }^{(4)}$. Also, the economic costs of HF must not be overlooked from the perspective the healthcare system ${ }^{(5)}$.

One of the factors responsible for the growing rates of HF is aging of the general population. This is associated with higher rates of comorbidities, such as ischaemic heart disease, peripheral atherosclerosis, lung conditions, diabetes mellitus, and chronic kidney disease $(\mathrm{CKD})^{(6)}$. Additionally, anaemia and iron deficiency have been receiving more and more attention recently ${ }^{(7-10)}$. The presence of these comorbidities may confound the diagnosis of HF and worsen both short-term and long-term prognoses ${ }^{(2,11-13)}$. Some of them are strongly related to the applied therapy - such as renal dysfunction, which in acutely decompensated HF (ADHF) may result either from inadequate function of the heart as a pump, or a too rapid and severe dehydration ${ }^{(14)}$. Thus, comprehensive evaluation of patients hospitalised due to ADHF is essential to determine the optimal treatment.

Therefore, the purpose of this study was to thoroughly assess a group of patients hospitalised due to ADHF, with a particular emphasis on the clinical presentation, comorbidities, and blood chemistry abnormalities.

\section{MATERIAL AND METHODS}

This prospective, observational study enrolled patients of both sexes, aged $\geq 18$ years who were admitted to the Department of Cardiology and Internal Diseases due to ADHF (defined according to the European Society of Cardiology guidelines ${ }^{(2)}$ ) in the period between November 2014 and March 2017 and required intravenous diuretic treatment. Exclusion criteria were: 1) unstable angina; 2) history of acute coronary syndrome (ACS) within the last 12 weeks and/or coronary artery bypass grafting (CABG) surgery within the last 12 weeks; 3 ) cardiac resynchronisation therapy (CRT) introduced within the last year (or planned CRT implantation within the next 24 months); 4) non-cardiogenic shock; 5) valvular disease or other acquired heart defects requiring surgical intervention; 6) hypertrophic cardiomyopathy; 7) severe pulmonary hypertension or other severe lung conditions (severe form of chronic obstructive pulmonary disease (COPD) or bronchial asthma); 8) poorly controlled hypertension; 9) anaemia (haemoglobin $<10.0 \mathrm{~g} / \mathrm{dL}$ ); 10) acute and/or decompensated non-cardiovascular disease; 11) pulmonary embolism; 12) end-stage CKD and/ inflammatory disease, severe infection (including febrile conditions, radiologically-confirmed pneumonia, suspected septic shock); 14) neoplastic disease; 15) severe psychiatric disorder; 16) the lack of informed consent.

The study protocol was approved by the Military Institute of Medicine Institutional Review Board (approval No. 14/WIM/2012), and all study participants provided their written informed consent. This study was registered at ClinicalTrials.gov (NCT 02355769).

Clinical examinations were conducted with a particular emphasis on the history of symptoms, concomitant diseases, and current medication. The following were measured on physical examination: heart rate (HR), office systolic blood pressure (SBP), office diastolic blood pressure (DBP), and body parameters (height, body weight, body mass index (BMI), waist circumference).

Laboratory tests were conducted on fasting peripheral venous blood samples collected in the morning (7:30-8:30 a.m.). The following whole-blood parameters were measured: haemoglobin levels, haematocrit, and red blood cell distribution width (RDW). The following were measured in blood serum: urea, creatinine, cystatin $\mathrm{C}$, fasting glucose (FG), uric acid (UA), total cholesterol (T-C), low-density lipoprotein cholesterol (LDL-C), high-density lipoprotein cholesterol (HDL-C), triglycerides (TG), N-terminal pro-brain natriuretic peptide (NT-proBNP), high-sensitivity troponin $\mathrm{T}$ (hsTnT), iron, ferritin (data available for $60 \mathrm{sub}-$ jects), unsaturated iron-binding capacity (UIBC), and total iron-binding capacity (TIBC). The cut-off values for nonstandard parameters, adopted depending on the laboratory techniques used, were as follows: cystatin $\mathrm{C}>0.95 \mathrm{mg} / \mathrm{L}$, creatinine $>1.2 \mathrm{mg} / \mathrm{dL}$, hsTnT $>14 \mathrm{ng} / \mathrm{L}$, iron $<70 \mu \mathrm{g} / \mathrm{dL}$, UA $>7 \mathrm{mg} / \mathrm{dL}$ for men and $>5.7 \mathrm{mg} / \mathrm{dL}$ for women. The value of estimated glomerular filtration rate (eGFR) was calculated with the MDRD (Modification of Diet in Renal Disease study) equation, which is a recognised method of calculating eGFR in patients with $\mathrm{HF}^{(15)}$. Abnormal NT-proBNP levels and iron deficiency criteria adopted for this study were based on the current guidelines ${ }^{(2)}$, i.e.: NT-proBNP levels of $>300 \mathrm{pg} / \mathrm{mL}$, iron deficiency when ferritin level was of $<100 \mu \mathrm{g} / \mathrm{L}$ and/or ferritin level of $100-299 \mu \mathrm{g} / \mathrm{L}$ with transferrin saturation (serum iron divided by TIBC and multiplied by $100 \%$ ) of $<20 \%$.

Echocardiographic examinations were conducted with Vivid S6 (GE-Healthcare, USA) and Vivid 7 (GE-Healthcare, Chicago, Illinois, USA) ultrasound systems. The following parameters were evaluated: cardiac chamber dimensions, left ventricular wall thickness and contractility, ejection fraction, as well as valvular structure and function. Echocardiography reports included any moderate-to-severe mitral, tricuspid, and/or aortic regurgitation; severe aortic stenosis; as well as the numerical values of the following parameters: left ventricular end-diastolic diameter (LVEDD), right ventricular end-diastolic diameter (RVEDD), interventricular septum (IVS), and left atrial diameter (LAD), measured in the parasternal long-axis view. 


\section{Statistical analysis}

The statistical analysis was conducted with the use of MS Office Excel 2013 and Statistica 12.0 (StatSoft Inc.). Data distribution was presented on histograms and evaluated visually. The results for qualitative variables were expressed as numbers and percentages; while continuous (quantitative) variables were expressed as means \pm standard deviation $(S D)$.

\section{RESULTS}

\section{Patient characteristics}

The study group comprised mostly men ( $n=78,76.5 \%)$; the mean age was $71.4 \pm 12.5$ years. Most patients $(n=66$, 64.7\%) had New York Heart Association (NYHA) class III symptoms, while 36 patients $(35.3 \%)$ reported symptoms at rest (NYHA class IV). Eleven patients (10.8\%) presented with decompensated HF in the form of pulmonary oedema. One-third ( $n=34,33.3 \%)$ of patients presented with new-onset HF. In nearly two-thirds ( $n=65,63.7 \%)$ of patients, the aetiology of HF decompensation was ischemic. The most commonly reported symptoms included dyspnoea on exertion, orthopnoea, and oedema (Tab. 1). Auscultation revealed evidence of pulmonary congestion in nearly all patients (98.1\%); three-fourths of patients presented with peripheral oedema. There were no cases of clinically significant bradycardia, and only $2 \%$ of patients had hypotension with SBP of $<90 \mathrm{~mm} \mathrm{Hg}$.

The detailed history of the patients' comorbidities is presented in Tab. 2. History-taking most commonly revealed ischemic heart disease, hypertension, atrial fibrillation, valvular disease, and diabetes mellitus. Tab. 3 lists medications used prior to admission (data obtained from 100 patients).

\section{Echocardiographic examination}

The echocardiographic examination was conducted in 97 patients. The mean left ventricular ejection fraction (LVEF) was $37.3 \pm 14.1 \%$, LVEDD was $59.2 \pm 10.2 \mathrm{~mm}$, RVEDD was $35.3 \pm 5.7 \mathrm{~mm}$, and LAD was $47.3 \pm 0.60 \mathrm{~mm}$. The following proportions of patients had moderate-to-severe valvular disease: mitral regurgitation (MR) 48.4\% $(n=47)$, tricuspid regurgitation (TR) $36.1 \%(n=35)$, aortic regurgitation (AR) $2.1 \%(n=2)$, and aortic stenosis (AS) $10.3 \%(n=10)$. The patients were stratified into three HF subgroups based on their LVEF values (Fig. 1).

\section{Laboratory tests}

Cardiac markers. The mean NT-proBNP levels were significantly elevated; the mean hsTnT levels of $<14 \mathrm{ng} / \mathrm{L}$ significantly exceeded the $99^{\text {th }}$ percentile value in a healthy reference population (Tab. 4). What is noteworthy is a pronounced right-skewed distribution of these variables,

\begin{tabular}{|c|c|}
\hline & $n(\%) /$ mean $\pm S D$ \\
\hline \multicolumn{2}{|l|}{ Interview } \\
\hline Dyspnoea at rest, $n(\%)$ & $41(40.2)$ \\
\hline Dyspnoea on effort, $n(\%)$ & $100(98.1)$ \\
\hline Orthopnoea, $n(\%)$ & $78(76.4)$ \\
\hline Paroxysmal nocturnal dyspnoea, $n(\%)$ & $44(43.1)$ \\
\hline Chest pain, $n(\%)$ & $25(24.5)$ \\
\hline Palpitations, $n(\%)$ & $33(32.4)$ \\
\hline Oedema, $n(\%)$ & 80 (78.4) \\
\hline Pathological weight gain, $n(\%)$ & $40(39.2)$ \\
\hline Loss of appetite, $n(\%)$ & $21(20.6)$ \\
\hline \multicolumn{2}{|l|}{ Physical examination } \\
\hline $\mathrm{HR}, 1 /$ min, mean $(S D)$ & $87.4 \pm 24.2$ \\
\hline SBP, mm Hg, mean (SD) & $135.4 \pm 26.8$ \\
\hline DBP, mm Hg, mean (SD) & $81.8 \pm 13.5$ \\
\hline $\begin{array}{l}\text { Hypertension (SBP >140 mm Hg, } \\
\text { DBP }>90 \mathrm{~mm} \mathrm{Hg}), n(\%)\end{array}$ & $26(25.5)$ \\
\hline Hypotension (SBP <90 mm Hg), $n(\%)$ & $2(1.9)$ \\
\hline Tachycardia > 120 bpm, $n(\%)$ & $7(6.7)$ \\
\hline Bradycardia $<40$ bpm, $n(\%)$ & $0(0.0)$ \\
\hline Tachypnoe, $n(\%)$ & $21(20.6)$ \\
\hline Rales, $n(\%)$ & $100(98.1)$ \\
\hline Oedema, $n(\%)$ & $77(75.5)$ \\
\hline Ascites, $n(\%)$ & $16(15.7)$ \\
\hline Peripheral hypoperfusion, $n(\%)$ & $10(9.8)$ \\
\hline Hepatomegaly, $n(\%)$ & $18(17.7)$ \\
\hline
\end{tabular}

Tab. 1. Patient characteristics

\begin{tabular}{|l|c|}
\hline Concomitant disease & $\boldsymbol{n}(\%)$ \\
\hline Prior MI, $n$ (\%) & $42(41.1)$ \\
\hline Procedure: CABG, $n$ (\%) & $18(17.6)$ \\
\hline Procedure: PTCA, $n$ (\%) & $36(35.3)$ \\
\hline Hypertension, $n$ (\%) & $68(66.6)$ \\
\hline Atrial fibrillation, $n$ (\%) & $54(52.9)$ \\
\hline Moderate-to-severe valvular disease, $n$ (\%) & $60(58.8)$ \\
\hline Procedure: prior surgical treatment of valvular disease, $n$ (\%) & $12(11.7)$ \\
\hline Procedure: ICD, $n$ (\%) & $10(9.8)$ \\
\hline Procedure: (RT, $n$ (\%) & $6(5.9)$ \\
\hline Procedure: PPM, $n$ (\%) & $16(15.7)$ \\
\hline Prior stroke, $n$ (\%) & $9(8.8)$ \\
\hline Peripheral artery disease, $n$ (\%) & $6(5.9)$ \\
\hline Diabetes mellitus, $n$ (\%) & $50(49.0)$ \\
\hline COPD, $n$ (\%) & $15(14.7)$ \\
\hline CKD (stadium $\geq 3), n$ (\%) & $30(29.4)$ \\
\hline Smoking, $n$ (\%) & \\
\hline \multicolumn{1}{|c|}{ Actually } & 14 (13.7) \\
\hline \multicolumn{1}{|l}{ In the past } & $58(56.9)$ \\
\hline $\begin{array}{l}\text { Data are presented as } n \text { (\%). } \\
\text { CABG - coronary artery bypass graft; CKD - chronic kidney disease, } \\
\text { GFR <60 ml/min/1,73 m²; COPD - chronic obstructive pulmonary disease; } \\
\text { CRT - cardiac resynchronisation therapy; ICD - implantable cardioverter } \\
\text { defibrillator; MI - myocardial infarction; PPM - permanent pacemaker; } \\
\text { PTCA - percutaneous transluminal coronary angioplasty. }\end{array}$ \\
\hline
\end{tabular}

Tab. 2. Patient characteristics - medical history 


\begin{tabular}{|l|c|c|}
\hline \multirow{2}{*}{} & \multicolumn{2}{|c|}{$\boldsymbol{n}$ (\%) } \\
\cline { 2 - 3 } & $\begin{array}{c}\text { Whole group } \\
(\boldsymbol{n}=\mathbf{1 0 0})\end{array}$ & $\begin{array}{c}\text { Prior HF } \\
(\boldsymbol{n}=\mathbf{6 7})\end{array}$ \\
\hline ACE-I, $n(\%)$ & $62(62.0)$ & $46(68.7)$ \\
\hline ARB, $n$ (\%) & $10(10.0)$ & $7(10.4)$ \\
\hline Beta-blocker, $n$ (\%) & $78(78.0)$ & $60(89.6)$ \\
\hline Aldosterone antagonists, $n$ (\%) & $33(33.0)$ & $28(41.8)$ \\
\hline Diuretics, $n$ (\%) & $74(74.0)$ & $60(89.6)$ \\
\hline Iwabradine, $n$ (\%) & $2(2.0)$ & $1(1.5)$ \\
\hline Digoxin, $n$ (\%) & $7(7.0)$ & $5(7.5)$ \\
\hline Amiodarone, $n(\%)$ & $13(13.0)$ & $12(17.9)$ \\
\hline Nitrates, $n$ (\%) & $12(12.0)$ & $9(13.4)$ \\
\hline Calcium channel blocker, $n$ (\%) & $21(21.0)$ & $11(16.4)$ \\
\hline Statin, $n$ (\%) & $58(58.0)$ & $49(73.1)$ \\
\hline Antiplatelet, $n$ (\%) & $37(37.0)$ & $30(44.8)$ \\
\hline Anticoagulants, $n$ (\%) & $47(47.0)$ & $38(56.7)$ \\
\hline $\begin{array}{l}\text { Data are presented as } n \text { (\%) } \\
\text { ACE-I - angiotensin-converting enzyme inhibitor; ARB - angiotensin } \\
\text { receptor blocker. } \\
\text { Data available for } n=100 .\end{array}$ & \\
\hline
\end{tabular}

Tab. 3. Patient characteristics - medication use before hospitalisation

with the median and interquartile range for NT-proBNP $3,952 \mathrm{pg} / \mathrm{mL}$ and $1,775-8,181 \mathrm{pg} / \mathrm{mL}$, respectively, and for hsTnT $35.3 \mathrm{ng} / \mathrm{L}$ and $23.0-58.7 \mathrm{ng} / \mathrm{L}$, respectively.

Renal function and metabolic parameters. In over a half of patients, eGFR values were $<60 \mathrm{~mL} / \mathrm{min} / 1.73 \mathrm{~m}^{2}$ (Tab. 4, Fig. 2). At the same time, nearly all patients (94.7\%), including the 42 patients (89.4\%) with eGFR of $>60 \mathrm{~mL} / \mathrm{min} / 1.73 \mathrm{~m}^{2}$, had elevated cystatin C levels (Fig. 3). The metabolic parameter of note was uric acid, whose levels were significantly elevated (hyperuricaemia) in $75.5 \%$ of patients.

Iron metabolism and haematology parameters. Over a half of the evaluated patients (55.9\%) were diagnosed

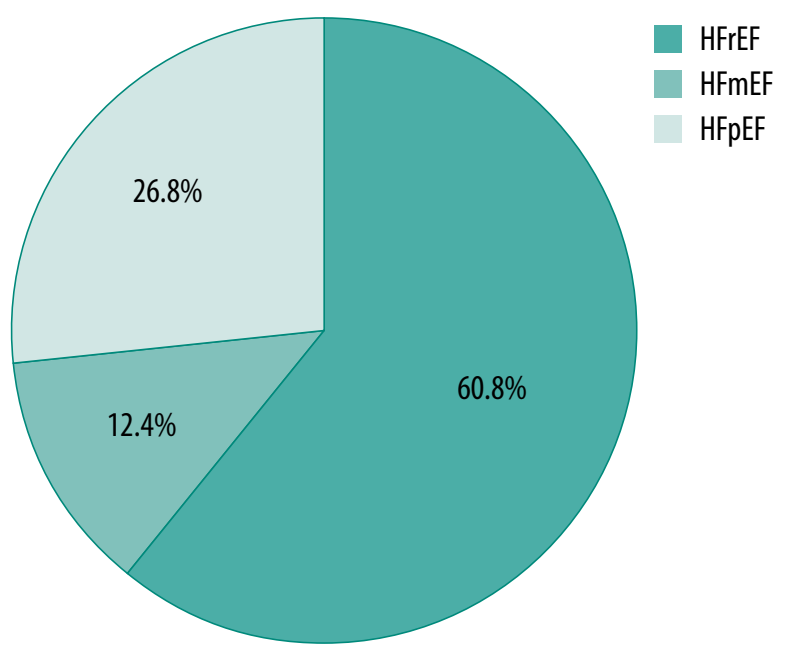

Fig. 1. HF categories in the studied group (HFrEF - HF with reduced ejection fraction, $<40 \%$; HFmEF - HF with midrange ejection fraction, $40-49 \%$; HFpEF - HF with preserved ejection fraction, $\geq 50 \%$ ) with anaemia (Tab. 4). Over three-fourths (78.3\%, data for 60 subjects) of them demonstrated iron deficiency.

\section{DISCUSSION}

A detailed assessment of patients with ADHF demonstrated the complexity of clinical issues to consider during the diagnosis and treatment of this condition. Clinical examinations revealed high rates of prognosis-worsening comorbidities in the study population. A detailed assessment of blood chemistry parameters proved that a number of disorders might remain undetected until hospital admission. Expanding the panel of diagnostic tests (to include cystatin C level, red blood cell parameters, and iron metabolism parameters) allowed us to identify clinically significant disorders associated with decompensated HF.

Medical history and clinical presentation. The study group was predominantly male, the mean age was over 70 years, and the most common cause of HF was post-infarct left-ventricular remodelling. The baseline characteristics of our study group were consistent with the data from the following HF-related registries: ATTEND ${ }^{(16)}$, ADHERE $^{(17)}$, OPTIMIZE-HF ${ }^{(18)}$, and EHFS II ${ }^{(19)}$ (Tab. 5). In one-third of patients, clinical decompensation was the first manifestation of undiagnosed HF, which is consistent with the data from large registries ${ }^{(19,20)}$. Pulmonary oedema was detected in $11 \%$ of the patients, which made it a relatively rare clinical presentation in comparison with the rates reported in earlier studies $(16-37 \%)^{(19,20)}$. Hypotension was present in only 1 out of 50 patients, which is consistent with the current knowledge ${ }^{(2)}$. This last finding supports the use of nitroglycerin (a vasodilatory agent), which can be safely administered in most ADHF patients ${ }^{(2)}$. Still, this is not so in common practice; according to various registries nitroglycerin is administered in less than a half of ADHF patients $^{(19,21-24)}$.

Echocardiographic findings. Although the study group comprised predominantly patients with HF with reduced ejection fraction (HFrEF), there was also a considerable proportion of patients with HFpEF (HF with preserved ejection fraction). Our findings confirmed earlier observations. According to relevant registries, $40-50 \%$ of patients hospitalised due to ADHF had normal, or nearly normal, left ventricular systolic function ${ }^{(25-28)}$. Thirty percent of patients in the NHFA study ${ }^{(27)}$ and $26 \%$ of patients in the RELAX-AHF study had LVEF of $>50 \%{ }^{(29)}$.

Treatment. Despite the fact that two-thirds of the evaluated patients had already been diagnosed with HF prior to their hospitalisation, the treatment they had been receiving was not optimal. Over $20 \%$ of patients received neither angiotensinconverting enzyme (ACE) inhibitors nor angiotensin II receptor blockers (ARBs), and $10 \%$ of patients received no betablocker. At the same time, nearly all patients $(90 \%)$ required treatment with diuretics. The data reported by others are no more reassuring. In the JCARE-CARD study ${ }^{(24,25)}$ only $51.2 \%$ of patients received ACE inhibitors or ARBs, with a similar 


\begin{tabular}{|c|c|}
\hline & $n(\%) /$ mean $\pm S D$ \\
\hline \multicolumn{2}{|l|}{ Cardiac biomarkers } \\
\hline NT-proBNP101a, pg/mL, mean (SD) & $6197 \pm 7057$ \\
\hline hsTnT ${ }^{100}, \mathrm{ng} / \mathrm{L}$, mean $(S D)$ & $103.1 \pm 257.5$ \\
\hline \multicolumn{2}{|l|}{ Renal parameters } \\
\hline Creatinine ${ }^{102}, \mathrm{mg} / \mathrm{dL}$, mean (SD) & $1.31 \pm 0.51$ \\
\hline Urea $^{102}, \mathrm{mg} / \mathrm{dL}$, mean (SD) & $54.0 \pm 26.2$ \\
\hline eGFR MDRD ${ }^{102}, \mathrm{~mL} / \mathrm{min} / 1.73 \mathrm{~m}^{2}$, mean (SD) & $62.2 \pm 23.9$ \\
\hline Cystatin $\mathrm{C}^{95}, \mathrm{mg} / \mathrm{dL}$, mean $(S D)$ & $1.62 \pm 0.58$ \\
\hline Cystatin C >0.95 mg/ ${ }^{95}, n(\%)$ & $90(94.7)$ \\
\hline \multicolumn{2}{|l|}{ Metabolic parameters } \\
\hline Glucose ${ }^{102}, \mathrm{mg} / \mathrm{dL}$, mean $(S D)$ & $137.7 \pm 76.0$ \\
\hline $\mathrm{TC}^{98}, \mathrm{mg} / \mathrm{dL}$, mean $(\mathrm{SD})$ & $136.7 \pm 47.1$ \\
\hline $\mathrm{HDL}-\mathrm{C}^{98}, \mathrm{mg} / \mathrm{dL}$, mean $(S D)$ & $43.1 \pm 16.8$ \\
\hline LDL- ${ }^{98}, \mathrm{mg} / \mathrm{dL}$, mean $(S D)$ & $87.5 \pm 38.9$ \\
\hline $\mathrm{TG}^{98}, \mathrm{mg} / \mathrm{dL}$, mean $(S D)$ & $100.8 \pm 53.9$ \\
\hline $\mathrm{UA}^{98}, \mathrm{mg} / \mathrm{dL}$, mean $(S D)$ & $8.52 \pm 2.37$ \\
\hline $\begin{array}{l}\text { Hyperuricaemia, }>7 \mathrm{mg} / \mathrm{dL}[\mathrm{M}] \text { and }>5.7 \mathrm{mg} / \mathrm{dL}[\mathrm{F}]^{98} \text {, } \\
n(\%)\end{array}$ & $74(75.5)$ \\
\hline \multicolumn{2}{|l|}{ Iron parameters } \\
\hline Iron ${ }^{97}, \mu \mathrm{g} / \mathrm{dL}$, mean $(S D)$ & $56.4 \pm 28.3$ \\
\hline Ferritin ${ }^{60}, \mu \mathrm{g} / \mathrm{L}$, mean (SD) & $144.4 \pm 197.5$ \\
\hline $\mathrm{UIBC}{ }^{97}, \mu \mathrm{g} / \mathrm{dL}$, mean $(S D)$ & $273.8 \pm 79.2$ \\
\hline $\mathrm{TIBC}^{97}, \mu \mathrm{g} / \mathrm{dL}$, mean $(S D)$ & $327.2 \pm 76.5$ \\
\hline Transferrin saturation ${ }^{97}, \%$, mean (SD) & $18.3 \pm 10.9$ \\
\hline $\begin{array}{l}\text { Iron deficiency (ferritin }<100 \mu \mathrm{g} / \mathrm{L} \text { and/or ferritin } \\
100-299 \mu \mathrm{g} / \mathrm{L} \text { with transferrin saturation }<20 \%)^{60}, n(\%)\end{array}$ & $45(78.3)$ \\
\hline \multicolumn{2}{|l|}{ Parameters of blood morphology } \\
\hline $\mathrm{WBC}^{102}, \mathrm{k} / \mathrm{m}^{3}$, mean $(S D)$ & $8.59 \pm 3.61$ \\
\hline $\mathrm{RBC}{ }^{102}, \mathrm{mln} / \mathrm{m}^{3}$, mean $(S D)$ & $4.35 \pm 0.79$ \\
\hline $\mathrm{Hb}^{102}, \mathrm{~g} / \mathrm{dL}$, mean (SD) & $12.6 \pm 2.6$ \\
\hline $\mathrm{RDW}^{99}, \mathrm{~g} / \mathrm{dL}$, mean (SD) & $15.5 \pm 2.6$ \\
\hline Hematocrit ${ }^{102}, \%$, mean (SD) & $38.5 \pm 6.2$ \\
\hline Anaemia $(\mathrm{Hb}<13 \mathrm{~g} / \mathrm{dL}[\mathrm{M}], \mathrm{Hb}<12 \mathrm{~g} / \mathrm{dL}[\mathrm{F}])^{102}, n(\%)$ & $57(55.9)$ \\
\hline \multicolumn{2}{|c|}{$\begin{array}{l}\text { a The upper index indicates the number of patients in whom the given } \\
\text { parameter was determined. } \\
\text { Data are presented as mean. } \\
\text { eGFR - estimated glomerular filtration rate; Hb - haemoglobin; } \\
\text { HDL-C - high-density lipoprotein cholesterol; hsTnT - high-sensitivity } \\
\text { troponin T; LDL-C - low-density lipoprotein cholesterol; } \\
\text { MDRD - Modification of Diet in Renal Disease Study; } \\
\text { NT-proBNP - N-terminal pro-brain natriuretic peptide; RBC - red blood } \\
\text { cells; RDW - red cell width; TC - total cholesterol; TG - triglicerydes; } \\
\text { TIBC - total iron-binding capacity; UA - uric acid; UIBC - unsaturated iron- } \\
\text { binding capacity; WBC - white blood cells. }\end{array}$} \\
\hline
\end{tabular}

Tab. 4. Patient characteristics - laboratory data on admission

proportion (63.1\%) reported in the EHFS II study ${ }^{(19)}$. An even lower proportion of patients in these studies received betablocker therapy (22\% and $43.2 \%$, respectively).

Comorbidities. Overall, the comorbidity profile in our study group was similar to that reported in large registries and clinical trials (Tab. 4), with only somewhat higher rates of diabetes mellitus (44\%) in our study (EHFS II - 32.8\% ${ }^{(19)}$, JCARE-CARD - $29.8 \%{ }^{(24)}$ ). We observed high proportion of patients with atrial fibrillation, which is consistent with the data from Polish registries $(56.8 \%)^{(30)}$.

Laboratory tests. Extending the scope of laboratory diagnostics revealed that a number of concomitant disorders of

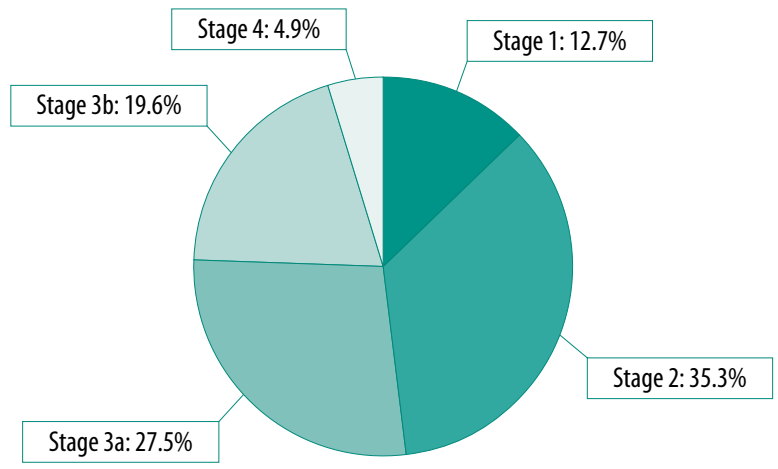

Fig. 2. Categories of CKD according to eGFR (stage $1-e G F R$ $>90 \mathrm{~mL} / \mathrm{min} / 1.73 \mathrm{~m}^{2}$, stage 2 - eGFR $60-89 \mathrm{~mL} /$ $\mathrm{min} / 1.73 \mathrm{~m}^{2}$, stage $3 a-45-59 \mathrm{~mL} / \mathrm{min} / 1.73 \mathrm{~m}^{2}$, stage $3 b-e G F R$ 30-44 $\mathrm{mL} / \mathrm{min} / 1.73 \mathrm{~m}^{2}$, stage $4-e G F R$ $<30 \mathrm{~mL} / \mathrm{min} / 1.73 \mathrm{~m}^{2}$ )

Cystatin C >0.95 mg/L

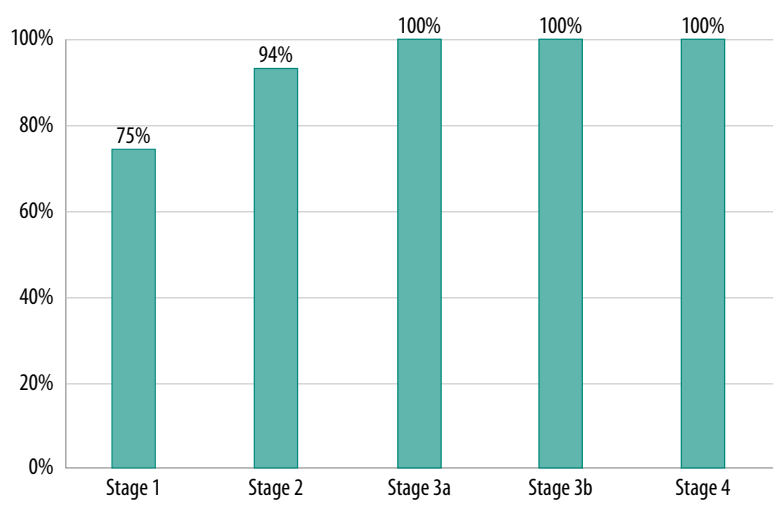

Fig. 3. Percentage of patients with elevated cystatin $C$ values in the subsequent stages of CKD (stage $1-e G F R>90 \mathrm{~mL}$ / $\mathrm{min} / 1.73 \mathrm{~m}^{2}$, stage 2 - eGFR $60-89 \mathrm{~mL} / \mathrm{min} / 1.73 \mathrm{~m}^{2}$, stage $3 a-45-59 \mathrm{~mL} / \mathrm{min} / 1.73 \mathrm{~m}^{2}$, stage $3 b-e G F R$ 30-44 $\mathrm{mL} / \mathrm{min} / 1.73 \mathrm{~m}^{2}$, stage 4 - eGFR $<30 \mathrm{~mL} / \mathrm{min} / 1.73 \mathrm{~m}^{2}$ )

high prognostic importance remain undiagnosed until hospitalisation. Anamnesis revealed CKD in $29.4 \%$ of patients, whereas baseline tests showed eGFR of $<60 \mathrm{~mL} / \mathrm{min} / 1.73 \mathrm{~m}^{2}$ in $60 \%$ of patients. The authors of large registries: JCARE-CARD ${ }^{(24)}$, ADHERE ${ }^{(17)}$ and EHFS II ${ }^{(19)}$ reported CKD rates of $11.3 \%, 30.0 \%$, and $16.8 \%$, respectively. In contrast to eGFR values, cystatin C levels indicated that only $5 \%$ of patients may have had unimpaired kidney function. Increased cystatin $\mathrm{C}$ was noted even in patients with normal creatinine levels and eGFR values of $>90 \mathrm{~mL} / \mathrm{min} / 1.73 \mathrm{~m}^{2}$. Thus, the addition of cystatin $\mathrm{C}$ level testing in evaluating renal function in patients with HF seems justified. A study by Breidthardt et al. ${ }^{(31)}$ demonstrated that elevated cystatin $\mathrm{C}$ levels in patients with ADHF was a risk factor for all-cause mortality and that it was independent of brain natriuretic peptide (BNP) levels. Importantly, cystatin $\mathrm{C}$ levels are independent of the age or muscle mass, in contrast to creatinine $e^{(32,33)}$.

The assessment of red blood cell parameters conducted as part of our study showed both anaemia and abnormal RDW 


\begin{tabular}{|c|c|c|c|c|c|c|}
\hline & Study group & EHFS II ${ }^{(19)}$ & ADHERE ${ }^{(17)}$ & OPIMIZE-HF (18) & ATTEND ${ }^{(16)}$ & JCARE-CARD ${ }^{(24)}$ \\
\hline \multicolumn{7}{|l|}{ Feature } \\
\hline$H R, 1 / \min$ & 87.4 & NA & NA & 86.6 & 99 & 87.8 \\
\hline SBP, $\mathrm{mm} \mathrm{Hg}$ & 135.4 & 132.1 & 143.8 & 142.7 & 147 & 134.3 \\
\hline $\mathrm{DBP}, \mathrm{mm} \mathrm{Hg}$ & 81.8 & NA & 79 & 76.4 & NA & 75.4 \\
\hline Dyspnea at rest, $\%$ & 40.2 & NA & 34 & 44 & NA & 66.7 \\
\hline Dyspnea on effort, $\%$ & 98.1 & NA & 89 & 61 & NA & 85.8 \\
\hline Orthopnea, \% & 77.2 & NA & NA & 27.4 & 68.5 & NA \\
\hline 0edema, $\%$ & 75.5 & NA & 65 & 65 & 67.7 & 53.3 \\
\hline Rale, \% & 98.1 & NA & 68 & NA & 77.6 & 51.7 \\
\hline \multicolumn{7}{|l|}{ Medical history, $\%$} \\
\hline Hypertension & 66.6 & 62.5 & 73 & 71 & 70.6 & 52.1 \\
\hline Diabetes mellitus & 49 & 32.8 & 44 & 42 & 34 & 29.8 \\
\hline Renal dysfunction & 29.7 & 16.8 & 30 & 20 & NA & 11.3 \\
\hline Anaemia & 55.9 & 14.7 & 53 & 18 & NA & 20.3 \\
\hline COPD & 14.7 & 19.3 & 31 & 28 & 9 & 5.8 \\
\hline Atrial fibrillation & 52.9 & 38.7 & 31 & 31 & 40 & 34.9 \\
\hline \multicolumn{7}{|c|}{ Medication use before hospitalisation, $\%$} \\
\hline ACE-I & 62 & 55 & 41 & 40 & & 26.5 \\
\hline ARB & 10 & 9.3 & 12 & 12 & & 28.9 \\
\hline Beta-blocker & 78 & 43.2 & 48 & 53 & & 22.3 \\
\hline MRA & 33 & 28.1 & NA & 7 & & 24.1 \\
\hline Diuretics & 74 & 71.2 & 70 & 65.7 & & 61 \\
\hline
\end{tabular}

Tab. 5. Comparison of the basic characteristics of the studied group with data from large registers

values to be common in ADHF patients. Anaemia was detected in $56 \%$ of patients, whereas in the Polish population of the HF Pilot Survey registry it was present in only close to one-fourth of patients ${ }^{(30)}$. The mean RDW value in our study group was $15.3 \%$, which falls within the upper interquartile range reported by others investigating this parameter in HF patients ${ }^{(34)}$. Wasilewski et al. ${ }^{(34)}$ observed significantly lower LVEF and larger left ventricular dimensions in a subgroup with the highest RDW (>14.6\%) compared with these parameters in the subgroup with the lowest RDW values. Moreover, the highest RDW subgroup demonstrated 8 -fold higher mortality than that observed in the subgroup with the lowest RDW.

Out of our study population $78.3 \%$ of patients exhibited iron deficiency. Iron deficiency has a negative effect on cardiomyocyte metabolism and function, and triggers sympathetic system activation, which may be one of the causes of HF decompensation ${ }^{(35)}$. The treatment of this metabolic disorder is particularly important in the light of reports on the beneficial effects of intravenous iron supplementation in patients with chronic $\mathrm{HF}^{(8,36,37)}$.

Of note is also the observed high proportion of patients with elevated UA levels. Hyperuricaemia in $75 \%$ of patients was a surprising finding, especially when compared with the its considerably lower prevalence reported in the available literature (in $43 \%$ of patients with HFrEF and in 57\% of patients with $\mathrm{HFpEF})^{(38)}$. One of the factors responsible for hyperuricaemia may be long-term diuretic therapy ${ }^{(39)}$. However, even this fails to explain the extent of this phenomenon. The important clinical issue in such cases is selecting the course of treatment as well as determining whether all such patients should receive xanthine oxidase inhibitors (as has been suggested by some experts ${ }^{(40)}$ ).

We consider these observed chemical imbalances to be a particularly important finding, as their presence proves the complex pathophysiology of ADHF. Although any causal relationships in this case are difficult to ascertain, establishing a treatment protocol that would incorporate controlling these abnormalities may have a great impact on prognosis in these patients. Certainly this topic requires further studies.

\section{STUDY LIMITATIONS}

The possibility to extrapolate our findings onto all patients with ADHF is limited by some of our exclusion criteria. For instance, we excluded patients with acute coronary syndrome, who had not been excluded from some registries (EHFS II). Due to the scope of study methods, not all patients with ADHF who were admitted to our Department consented to participate, which limited our sample size. Another limitation, in a sense, is the fact that the echocardiographic examination was conducted after a varied length of time post-admission. Because of this, the findings may 
not accurately reflect the LVEF or the severity of valvular disease at the moment when the decompensation was the most pronounced. The few instances of missing data, indicated in the Results section, should not have any significant effect on data interpretation.

\section{CONCLUSION}

The diagnosis and treatment of patients with ADHF require a comprehensive approach. Most of such patients suffer from concomitant conditions with a documented impact on prognosis. Cardiovascular decompensation poses a risk of multi-organ dysfunction and estimating its actual consequences requires a detailed clinical assessment and additional diagnostic evaluations. Expanding the scope of laboratory tests to include cystatin $\mathrm{C}$, red blood cell parameters, and iron metabolism parameters, helps identify pathophysiologically significant abnormalities, which should not be overlooked during the treatment of patients with HF.

\section{Conflict of interest}

None declared.

\section{Funding}

The study was supported by the Ministry of Science and Higher Education/Military Institute of Medicine, Warsaw, Poland (grant No. 213/WIM, awarded to PK).

\section{Acknowledgements}

We would like to thank the medical staff of our department for the nursing care and data collection.

\section{References}

1. Rywik TM, Koziarek J, Piotrowski W et al.: Trends in heart failure mortality in Poland between 1980 and 2010. Pol Arch Med Wewn 2013; 123: 664-671.

2. Ponikowski P, Voors AA, Anker SD et al.; Authors/Task Force Members; Document Reviewers: 2016 ESC Guidelines for the diagnosis and treatment of acute and chronic heart failure: the Task Force for the diagnosis and treatment of acute and chronic heart failure of the European Society of Cardiology (ESC). Developed with the special contribution of the Heart Failure Association (HFA) of the ESC. Eur J Heart Fail 2016; 18: 891-975.

3. Mosterd A, Hoes AW: Clinical epidemiology of heart failure. Heart 2007; 93: 1137-1146.

4. Cowie MR, Anker SD, Cleland JGF et al.: Improving care for patients with acute heart failure: before, during and after hospitalization. ESC Heart Fail 2014; 1: 110-145.

5. Czech M, Opolski G, Zdrojewski T et al.: The costs of heart failure in Poland from the public payer's perspective. Polish programme assessing diagnostic procedures, treatment and costs in patients with heart failure in randomly selected outpatient clinics and hospitals at different levels of care: POLKARD. Kardiol Pol 2013; 71: 224-232.

6. Fernandez-Gasso L, Hernando-Arizaleta L, Palomar-Rodríguez JA et al.: Trends, causes and timing of 30-day readmissions after hospitalization for heart failure: 11-year population-based analysis with linked data. Int J Cardiol 2017; 248: 246-251.
7. Scrutinio D, Passantino A, Guida P et al.: Prognostic impact of comorbidities in hospitalized patients with acute exacerbation of chronic heart failure. Eur J Intern Med 2016; 34: 63-67.

8. Ponikowski P, van Veldhuisen DJ, Comin-Colet J et al.; CONFIRM-HF Investigators: Beneficial effects of long-term intravenous iron therapy with ferric carboxymaltose in patients with symptomatic heart failure and iron deficiency. Eur Heart J 2015; 36: 657-668.

9. Cohen-Solal A, Damy T, Terbah M et al.: High prevalence of iron deficiency in patients with acute decompensated heart failure. Eur J Heart Fail 2014; 16: 984-991.

10. Klip IT, Comin-Colet J, Voors AA et al.: Iron deficiency in chronic heart failure: an international pooled analysis. Am Heart J 2013; 165: 575-582.e3.

11. Arora S, Patel P, Lahewala $S$ et al.: Etiologies, trends, and predictors of 30-day readmission in patients with heart failure. Am J Cardiol 2017; 119: 760-769.

12. Arora S, Lahewala S, Hassan Virk HU et al.: Etiologies, trends, and predictors of 30-day readmissions in patients with diastolic heart failure. Am J Cardiol 2017; 120: 616-624.

13. O'Meara E, Rouleau JL, White M et al.; ANCHOR Investigators: Heart failure with anemia: novel findings on the roles of renal disease, interleukins, and specific left ventricular remodeling processes. Circ Heart Fail 2014; 7: 773-781.

14. Damman K, Valente MAE, Voors AA et al.: Renal impairment, worsening renal function, and outcome in patients with heart failure: an updated meta-analysis. Eur Heart J 2014; 35: 455-469.

15. Smilde TD, van Veldhuisen DJ, Navis G et al.: Drawbacks and prognostic value of formulas estimating renal function in patients with chronic heart failure and systolic dysfunction. Circulation 2006; 114: 1572-1580.

16. Sato N, Kajimoto K, Asai K et al.: Acute decompensated heart failure syndromes (ATTEND) registry. A prospective observational multicenter cohort study: rationale, design, and preliminary data. Am Heart J 2010; 159: 949-955.e1.

17. Adams KF Jr, Fonarow GC, Emerman CL et al.; ADHERE Scientific Advisory Committee and Investigators: Characteristics and outcomes of patients hospitalized for heart failure in the United States: rationale, design, and preliminary observations from the first 100,000 cases in the Acute Decompensated Heart Failure National Registry (ADHERE). Am Heart J 2005; 149: 209-216.

18. Fonarow GC, Abraham WT, Albert NM et al.: Organized Program to Initiate Lifesaving Treatment in Hospitalized Patients with Heart Failure (OPTIMIZE-HF): rationale and design. Am Heart J 2004; 148: 43-51.

19. Nieminen MS, Brutsaert D, Dickstein K et al.; EuroHeart Survey Investigators; Heart Failure Association, European Society of Cardiology: EuroHeart Failure Survey II (EHFS II): a survey on hospitalized acute heart failure patients: description of population. Eur Heart J 2006; 27: 2725-2736.

20. Follath F, Yilmaz MB, Delgado JF et al.: Clinical presentation, management and outcomes in the Acute Heart Failure Global Survey of Standard Treatment (ALARM-HF). Intensive Care Med 2011; 37: 619-626.

21. Carlson MD, Eckman PM: Review of vasodilators in acute decompensated heart failure: the old and the new. J Card Fail 2013; 19: 478-493.

22. Costanzo MR, Johannes RS, Pine M et al.: The safety of intravenous diuretics alone versus diuretics plus parenteral vasoactive therapies in hospitalized patients with acutely decompensated heart failure: a propensity score and instrumental variable analysis using the Acutely Decompensated Heart Failure National Registry (ADHERE) database. Am Heart J 2007; 154: 267-277.

23. Aziz EF, Kukin M, Javed $F$ et al.: Effect of adding nitroglycerin to early diuretic therapy on the morbidity and mortality of patients with chronic kidney disease presenting with acute decompensated heart failure. Hosp Pract (1995) 2011; 39: 126-132.

24. Hamaguchi S, Kinugawa S, Tsuchihashi-Makaya M et al.: Characteristics, management, and outcomes for patients during hospitalization due to worsening heart failure - a report from the 
Japanese Cardiac Registry of Heart Failure in Cardiology (JCARE-CARD). J Cardiol 2013; 62: 95-101.

25. Tsuchihashi-Makaya M, Hamaguchi S, Kinugawa $S$ et al.; JCARE-CARD Investigators: Characteristics and outcomes of hospitalized patients with heart failure and reduced vs preserved ejection fraction. Report from the Japanese Cardiac Registry of Heart Failure in Cardiology (JCARE-CARD). Circ J 2009; 73 : 1893-1900.

26. Farré N, Lupon J, Roig E et al.; GICCAT Investigators: Clinical characteristics, one-year change in ejection fraction and longterm outcomes in patients with heart failure with mid-range ejection fraction: a multicentre prospective observational study in Catalonia (Spain). BMJ Open 2017; 7: e018719.

27. National Heart Failure Audit. April 2014 - March 2015.

28. Yancy CW, Lopatin M, Stevenson LW et al.; ADHERE Scientific Advisory Committee and Investigators: Clinical presentation, management, and in-hospital outcomes of patients admitted with acute decompensated heart failure with preserved systolic function: a report from the Acute Decompensated Heart Failure National Registry (ADHERE) Database. J Am Coll Cardiol 2006; 47: 76-84.

29. Filippatos G, Teerlink JR, Farmakis D et al.: Serelaxin in acute heart failure patients with preserved left ventricular ejection fraction: results from the RELAX-AHF trial. Eur Heart J 2014; 35: 1041-1050.

30. Fedyk-Łukasik M, Wizner B, Opolski G et al.: Quality of care of hospitalised patients with heart failure in Poland in 2013: results of the second nationwide survey. Kardiol Pol 2017; 75: 527-534.

31. Breidthardt T, Sabti Z, Ziller R et al.: Diagnostic and prognostic value of cystatin $C$ in acute heart failure. Clin Biochem 2017; 50: 1007-1013.
32. Fliser D, Ritz E: Serum cystatin C concentration as a marker of renal dysfunction in the elderly. Am J Kidney Dis 2001; 37: 79-83.

33. Westhuyzen J: Cystatin C: a promising marker and predictor of impaired renal function. Ann Clin Lab Sci 2006; 36: 387-394.

34. Wasilewski J, Pyka $€$, Hawranek $M$ et al.: Prognostic value of red blood cell distribution width in patients with left ventricular systolic dysfunction: insights from the COMMIT-HF registry. Cardiol J 2018; 25: 377-385.

35. Palazzuoli A, Gallotta M, Iovine F et al.: Niedokrwistość w niewydolności serca: częste współwystępowanie z niewydolnością nerek, czyli zespół niedokrwistości sercowonerkowej. Folia Cardiologica Excerpta 2008; 3: 264-270.

36. Ponikowski P, Filippatos G, Colet JC et al.; FAIR-HF Trial Investigators: The impact of intravenous ferric carboxymaltose on renal function: an analysis of the FAIR-HF study. Eur J Heart Fail 2015; 17: 329-339.

37. Gutzwiller FS, Pfeil AM, Comin-Colet J et al.: Determinants of quality of life of patients with heart failure and iron deficiency treated with ferric carboxymaltose: FAIR-HF sub-analysis. Int J Cardiol 2013; 168: 3878-3883.

38. Palazzuoli A, Ruocco G, De Vivo O et al.: Prevalence of hyperuricemia in patients with acute heart failure with either reduced or preserved ejection fraction. Am J Cardiol 2017; 120: 1146-1150.

39. Huang $\mathrm{H}$, Huang B, Li Y et al.: Uric acid and risk of heart failure: a systematic review and meta-analysis. Eur J Heart Fail 2014; 16: $15-24$.

40. Widecka K, Szymański FM, Filipiak KJ et al.: Stanowisko ekspertów dotyczące hiperurykemii i jej leczenia u pacjentów z wysokim ryzykiem sercowo-naczyniowym. Arterial Hypertens 2017; 21: 1-9. 